\title{
IMPLEMENTASI TATA TERTIB SEKOLAH DALAM MENINGKATKAN KARAKTER KEDISIPLINAN SISWA
}

\author{
Moh. Mansyur Fawaid \\ FKIP Universitas Muhammadiyah Malang, Indonesia \\ Email: mmansyurfawaid18@gmail.com
}

\begin{abstract}
ABSTRAK
Penelitian ini bertujuan untuk: (1) Mengetahui strategi tata tertib sekolah dalam meningkatkan pendidikan karakter kedisiplinan siswa di SMA Islam Al-Maarif Singosari; (2) Untuk mengetauhi implementasi tata tertib sekolah dalam menunjang pendidikan karakter kedisiplinan siswa di SMA Islam Al-Maarif Singosari; dan (3) Mengidentifikasi kendala yang di hadapi SMA Islam Al-Maarif Singosari dalam mengimplementasikan tata tertib sekolah dalam menunjang pendidikan karakter kedisiplinan. Jenis penelitian yang digunakan dalam penelitian ini adalah jenis penelitian Kualitatif Deskriptif. Sebagai sumber data dipilih kepala sekolah, tatib kesiswaan, serta peserta di SMAIslam Al-Maarif Singosari Malang. Waktu untuk penelitian ini dilakukan selama bulan maret sampai april 2017. Berdasarkan hasil penelitian dan pembahasan didapatkan hasil bahwa: (1) starategi yang dilakukan sekolah untuk meningkatkan pembentukan karakter disiplin adalah Pembiasaan kegiatan yang membentuk karakter disiplin adapun pembiasannya meliputi disiplin waktu dan model potongan rambut, cara berpakaian; (2) Implementasi tata tertib sekolah dalam meningkatkan pendidikan karakter kedisiplinan siswa di SMA Islam Al-Maarif Singosari SMA Islam AlMaarif Singosari telah menamkan pendidikan karakter disiplin melalui kegiatan keagamaan dan kegiatan-kegiatan yang berkaitan dengan pendidikan karakter kedisplinan seperti semacam peraturan model potongan rambut, displin waktu, sholat dhuha, dan sholat dhuhur berjamaah.
\end{abstract}

Kata Kunci: Kedisplinan siswa; Pendidikan karakter

\begin{abstract}
This study aims to: (1) Know the school discipline strategy in improving the character education of students' discipline in Al-Maarif Singosari Islamic High School (2). To understand the implementation of school discipline in supporting the character education of students in Al- Maarif Singosari Islamic High School. (3). Identify the obstacles faced by AlMaarif Singosari Islamic High School in implementing the school discipline in supporting disciplinary character education. The type of research used in this study is a type of qualitative qualitative research. As a source of data, the headmaster, student student, and participants at Al-Maarif Singosari Islamic High School Malang were chosen. This research was carried out in approximately 6 months. Based on the results of the research and discussion, the results of strategies conducted by schools to improve the formation of character discipline according to Mr. Arif as the Standing Person is the habit of activities that form the character of discipline while refracting includes the discipline of time and the model of haircut, how to dress. Implementation of the school discipline in improving the character education of student discipline in the Islamic High School Al-Maarif Singosari Islamic High School Al-Maarif Singosari has marked discipline character education through religious activities and activities related to discipline character education such as a kind of haircut model, time discipline, dhuha prayer, and dhuhur prayer in congregation.
\end{abstract}

Keywords: student discipline; character education 


\section{PENDAHULUAN}

Setiap kegiatan formal di sekolah tidak lepas dari tata tertib yang mengatur perilaku semua pihak pada lingkungan sekolah, salah satunya untuk peserta didik. Tata tertib yang berlaku berkaitan erat dengan perilaku disiplin yang masih menjadi permasalahan di sekolah. Tujuan utama tata tertib adalah melatih disiplin dan menanamkan disiplin moral dalam diri individu yang akan membentuk pola perilaku, sehingga tata tertib menjadi sebuah kontrol perilaku agar sesuai dengan peraturan.

Kenyataannya masalah yang sering terjadi dalam lingkungan sekolah adalah kurang disiplinnya peserta didik dalam menaati tata tertib yang berlaku di sekolah tersebut. Ketertiban peserta didik sering kali menjadi suatu masalah di sekolah, apalagi pada jenjang pendidikan sekolah menengah yang peserta didiknya beranjak dewasa dan mulai belajar mengenal jati diri yang dilakukan melalui peniruan diri atau imitasi. Pergaulan remaja yang tanpa arah dan pengawasan terhadap tingkah laku akan mempunyai kecenderungan mengarah pada pergaulan remaja yang negatif. Banyak anggapan dari peserta didik bahwa tata tertib sekolah hanya membatasi kebebasan sehingga berakibat pelanggaran tata tertib di sekolah. Tanpa disadari kebebasan yang tidak bertanggung jawab akan merugikan diri sendiri, keluarga dan masyarakat.

Pendidikan moral pada anak dimulai pada saat di lingkungan keluarga terutama orang tua melalui proses sosialisasi norma dan aturan moral dalam keluarga sendiri serta lingkungan dekat dengan pergaulan sosial anak atau teman sebaya. Kemudian saat anak masuk sekolah diperkenalkan dan diajarkan sesuatu yang baru yang tidak diajarkan dalam keluarga. Sekolah sebagai tempat sosialisasi kedua setelah keluarga serta tempat anak dihadapkan pada kebiasaan dan cara hidup bersama yang lebih luas ruang lingkupnya serta ada kemungkinan dengan kebiasaan dan cara hidup dalam keluarganya, sehingga berperan besar dalam menumbuhkan kesadaran moral diri anak. Kesadaran moral inilah yang nantinya akan menanamkan pendidikan karakter seperti kedisiplinan dalam diri anak.

Sekolah banyak sekali komponen yang dapat dijadikan sebagai sarana untuk pembentukan karakter kedisiplinan anak salah satunya adalah tata tertib sekolah, karena pada dasarkan penerapan tata tertib sekolah sesuai dengan tujuan pendidikan yaitu mengembangkan potensi kedisiplinan dan mencetak insan yang memiliki intelektual tinggi serta beraklakul karimah.

Kedisiplinan siswa dalam proses pembelajaran merupakan hal yang sangat penting dan perlu diperhatikan sehingga proses belajar yang ditempuh benar-benar memperoleh hasil yang optimal khususnya dalam proses belajar mengajar yang berlangsung di sekolah yang banyak dipengaruhi oleh komponen belajar mengajar, misalnya siswa, guru, sarana dan prasarana belajar. Tentu dalam pelaksanaannya, kedisiplinan tidak serta merta langsung terwujud tanpa ada usaha yang dilakukan suatu lembaga pendidikan. Pelaksanaanya ada beberapa proses yang bisa jadi harus ditempuh untuk memupuk sebuah kedisiplinan dan di Islam AlMaarif Singosari salah satu sarana untuk menumbuhkan kedisiplinan adalah dengan memberlakukan tata tertib bagi setiap siswa-siswinya.

\section{Implementasi}

Implementasi adalah suatu tindakan atau pelaksanaan dari sebuah rencana yang sudah disusun secara matang dan terperinci. Implementasi biasanya dilakukan setelah perencanaan sudah dianggap sempurna. Implementasi adalah bermuara pada aktivitas, aksi, tindakan atau adanya mekanisme suatu sistem, implementasi bukan sekedar aktivitas, tapi suatu kegiatan yang terencana dan untuk mencapai tujuan kegiatan. 


\section{Tata Tertib}

Secara umum tata tertib sekolah dapat diartikan sebagai ikatan atau aturan yang harus dipatuhi setiap warga sekolah tempat berlangsungnya proses belajar mengajar. Pelaksanaan tata tertib sekolah akan dapat berjalan dengan baik jika Guru, aparat sekolah dan siswa telah saling mendukung terhadap tata tertib sekolah itu sendiri, kurangnya dukungan dari siswa akan mengakibatkan kurang berartinya tata tertib sekolah yang diterapkan di sekolah. Peraturan sekolah yang berupa tata tertib sekolah merupakan kumpulan aturan-aturan yang dibuat secara tertulis dan mengikat di lingkungan sekolah. Dari pengertian di atas dapat dipahami bahwa tata tertib sekolah merupakan satu kesatuan yang tidak dapat dipisahkan satu dengan yang lain sebagai aturan yang berlaku di sekolah agar proses pendidikan dapat berlangsung dengan efektif dan efisien.

\section{Sekolah}

Sekolah berasal dari Bahasa Latin: skhole, scola, scolae atau skhola yang memiliki arti: waktu luang atau waktu senggang, dimana ketika itu sekolah adalah kegiatan di waktu luang bagi anakanak di tengah-tengah kegiatan utama mereka, yaitu bermain dan menghabiskan waktu untuk menikmati masa anak-anak dan remaja. Kegiatan dalam waktu luang itu adalah mempelajari cara berhitung, cara membaca huruf dan mengenal tentang moral (budi pekerti) dan estetika (seni). Untuk mendampingi dalam kegiatan scola anakanak didampingi oleh orang ahli dan mengerti tentang psikologi anak, sehingga memberikan kesempatan yang sebesar-besarnya kepada anak untuk menciptakan sendiri dunianya melalui berbagai pelajaran di atas. Saat ini, kata sekolah berubah arti menjadi: merupakan bangunan atau lembaga untuk belajar dan mengajar serta tempat menerima dan memberi pelajaran. Menurut pendapat yang lain bahwa lingkungan sekolah adalah kesatuan ruang dalam lingkup pendidikan formal yang memberi pengaruh pembentukan sikap dan pengembangan potensi siswa.

\section{Pendidikan Karakter}

Pendidikan karakter berasal dari dua kata pendidikan dan karakter, menurut beberapa ahli, kata pendidikan mempunyai definisi yang berbeda-beda tergantung pada sudut pandang, paradigma, metodologi dan disiplin keilmuan yang digunakan, diantaranya: Pendidikan adalah "Bimbingan atau pembinaan secara sadar oleh pendidik terhadap perkembangan Jasmani dan Rohani anak didik menuju terbentuknya kepribadian yang utuh. Dewantara (2007) menyatakan bahwa pendidikan adalah daya upaya untuk memajukan budi pekerti, pikiran, dan jasmani anak agar selaras dengan alam dan masyarakatnya. Sedangkan secara terminologi, pengertian pendidikan banyak sekali dimunculkan oleh para pemerhati/tokoh pendidikan, di antaranya: Pertama, menurut Marimba pendidikan adalah bimbingan atau pimpinan secara sadar oleh pendidik terhadap perkembangan jasmani dan rohani anak didik menuju terbentuknya kepribadian yang utama.

\section{Kedisiplinan}

Disiplin adalah suatu kondisi yang tercipta dan terbentuk melalui proses dari serangkaian perilaku yang menunjukkan nilainilai ketaatan, kepatuhan, kesetiaan, keteraturan dan ketertiban. Disiplin akan membuat seseorang tahu dan dapat membedakan hal-hal apa yang seharusnya dilakukan, yang wajib dilakukan, yang boleh dilakukan, yang tak sepatutnya dilakukan (karena merupakan hal-hal yang dilarang). Bagi seorang yang berdisiplin, karena sudah menyatu dalam dirinya, maka sikap atau perbuatan yang dilakukan bukan lagi dirasakan sebagai beban, namun sebaliknya akan membebani dirinya apabila ia tidak berbuat disiplin. Nilai-nilai kepatuhan telah menjadi bagian dari perilaku dalam kehidupannya. Disiplin yang mantap pada hakikatnya akan tumbuh dan terpancar 
dari hasil kesadaran manusia. Sebaliknya, disiplin yang tidak bersumber dari kesadaran hati nurani akan menghasilkan disiplin yang lemah dan tidak akan bertahan lama, atau disiplin yang statis, tidak hidup.

\section{METODE}

\section{Jenis dan Pendekatan Penelitian}

Penelitian ini menggunakan penelitian kualitatif karena permasalahan yang di bahas dalam penelitian ini tidak berkenaan dengan angka-angka tetapi mendeskripsikan, menguraikan, dan menggambarkan tentang implementasi tata tertib sekolah dalam meningkatkan pendidikankarakterkedisiplinan siswa di sma islam al-maarif singosari.Tujuan penelitian kualitatif adalah menggambarkan dan mengungkap (to descrie and explore), dan menggambarkan dan menjelaskan (to describe dan explain). Kebanyakan penelitian kualitatif bersifat deskriptif dan eksplanatori. Penelitian kualitatif adalah suatu penelitian yang ditujukan untuk mendeskripsikan dan menganalisis fenomena, peristiwa, aktivitas sosial, sikap, kepercayaan, persepsi, pemikiran orang secara induvidu maupun kelompok.

\section{Tempat dan Waktu Penelitian}

Penelitian ini dilakukan di SMA Islam Al-Maarif Singosari. Waktu untuk penelitian ini dilakukan selama empat minggu yang di mulai bulan September sampai bulan Oktober dari tahap penyusunan proposal penelitian sampai dengan selesainya penulisan laporan penelitian.

\section{Prosedur Penelitian}

Berdasarkan kajian kepustakaan yang ada menurut Moleong (2001) tahaptahap penelitian kualitatif terdiri dari :

\section{Tahap Pra Lapangan}

Dalam kegiatan pra lapangan atau persiapan ini adalah beberapa tahapan yaitu: seorang tidak tergantung dari orang Merumuskan masalah yang ingin lain, dalam arti benar-benar seorang pribadi yang menentukan diri sendiri dan tidak dipaksa dari luar, mempunyai sifat-sifat dan keinginan sendiri.

1. Perumusan masalah dilakukan pada waktu pengajuan usulan penelitian dan diulangi kembali pada waktu penulisan laporan karena rumusan masalah merupakan salahsatu unsur yang tidak dapat dikesampingkan.

2. Peneliti menentukan tempat untuk penelitan, dalam penelitian ini peneliti mengambil lokasi penelitian di SMA Islam Al-Maarif Singosari.

3. Penyusunan proposal adalah syarat dalam menyampaikan penlitian kepada pihak terkait.

4. Melakukan pengurusan surat izin dalam hal ini peneliti harus mengurus di Universitas Muhammadiyah Malang. Surat izin penelitian ini berfungsi untuk sebagai bukti bahwa bisa melakukan penelitian ditempat yang menjadi tempat penelitian saya yaitu bertempat di SMA (Sekolah Menengah Atas) Islam Al- Maarif Singosari.

\section{Tahap Pelaksanaan Proses Lapangan}

Tahap ini merupakan tahap bekerja dilapangan yang meliputi tahap pengumpulan data dan tahap penyusunan data.

\section{Tahap Analisa Data.}

Tahap ini merupakan tahap dari analisis data yang diperoleh dari responden atau informan sesuai dengan rumusan masalah yang telah disusun secara sistematis.

\section{Tahap kesimpulan}

Setelah tahap analisis data maka tahap selanjutnya yang dilakukan adalah tahap kesimpulan. Tahap ini merupakan tahap untuk menarik kesimpulan data yang sudah di analisis dari responden. 


\section{Tahap pelaporan}

Tahap ini merupakan tahap penulisan laporan atau tahap akhir dari serangkaian dari beberapa prosedur penelitian kualitatif. Tahap pelaporan peneliti melakukan penyusunan laporan penelitian secara sistematis dengan data yang didapat dari responden.

\section{Subjek Penelitian}

Dalam penelitian tindakan kelas ini yang menjadi subjek penelitian adalah siswa di SMA Islam Al-Maarif Singosari.

\section{Instrumen Penelitian}

Instrumen Penelitian merupakan alat bantu bagi peneliti untuk mengumpulkan data. Kualitas instrumen akan menentukan kualitas data yang terkumpul. Zuriah (2007) menyatakan bahwa pada umumnya penelitian itu akan berhasil dengan baik apa bila banyak menggunakan instrumen, sebab data yang diperlukan menjawab pertanyaan penelitian (masalah peneliti) dan menguji hepotesis melaluhi instrumen. Berdasarkan teknik pengumpulan data yang digunakan, maka instrumen penelitian ini menggunakan panduan wawancara, panduan interview, dan panduan observasi.

\section{Teknik Pengumpulan Data}

Teknik pengumpulan data merupakan langkah yang paling utama dalam penelitian, karena tujuan utama dari penelitian adala mendapatkan data, tanpa mengetaui teknik pengumpulan data, maka peneliti tidak akan mendapatkan data yang memenuhi standar data yang ditetapkan. Penelitia kualitatif, data yang dikumpulkan dalam penelitian ini berupah kata-kata tertulis, tanya jawab, atau lisan dari orangorang dan perilaku yang dapat diamati, maka metode yang digunakan untuk proses pengumpulan data dalam penelitian adalah:

\section{Wawancara}

Wawancara merupakan salah satu bentuk teknik pengumpulan data yang dilaksanakan secara lisan dalam pertemuan tatap muka secara individu Wawancara diartikan sebagai proses tanya jawab lisan, yang mana dua orang atau lebih berhadaphadapan secara fisik, dimana dua orang yang hadap- hadapan tersebut dapat melihat muka dan dapat mendengarkan suara dan telinga sendiri secara langsung.

\section{Observasi}

Observasi diartikan sebagai pengamatan dan pencatatan dengan sistematika atas fenomena-fenomena yang akan diteliti, dapat juga diartikan dengan pengumpulan data melalui pemusatan perhatian secara langsung terhadap subjek dengan menggunakan indra yang dimiliki. Observasi merupakan suatu teknik atau cara pengumpulan data dengan jalan mengadakan pengamatan terhadap kegiatan yang sedang berlangsung Sukmadinata (2009).

\section{Teknik Analisis Data}

Menurut Patton (dikutip Moleong, 2001), analisis data adalah proses mengatur urutan data, mengorganisasikan kedalam suatu pola, kategori uraian dasar. Definisi tersebut memberikan gambaran betapa pentingnya kedudukan analisis data dilihat dari segi tujuan penelitian. Prinsip pokok penelitian kualitatif adalah menemukan teori data. Teknik analisis data yang digunakan dalam penelitian ini adalah menggunakan langkah-langkah seperti yang dikemukakan oleh Bugin (2010) yaitu:

\section{Pengumpulan Data (Data Collection)}

Pengumpulan data merupakan bagian integral dari kegiatan analisis data. Kegiatan pengumpulan data pada penelitian ini adalah dengan mengunakan wawancara, observasi, dan studi dokumentasi.

\section{Reduksi Data (Data Reduction)}

Setelah data tersebut terkumpul dan tercatat semua, selanjutnya direduksi yaitu menggolongkan, mengartikan, membuang yang tidak perlu dan mengorganisasikan sehingga nantinya muda dilakukan 
penarikan kesimpulan. Jika yang diperoleh kurang lengkap maka peneliti mencari kembali data yang diperlukan di lapangan.

\section{Penyajian Data (Display Data)}

Data yang telah direduksi tersebut merupakan sekumpulan informasi yang kemudian disusun atau diajukan sehingga memberikan kemungkinan adanya penarikan kesimpulan dan pengambilan tindakan.

\section{Penarikan Kesimpulan dan Verifikasi}

Setelah data disajikan, maka dilakukan penarikan kesimpulan atau verifikasi. Dalam penarikan kesimpulan atau verifikasi ini, didasarkan pada reduksi data yang merupakan jawaban atas masalah yang diangkat dalam penelitian ini.

\section{HASIL DAN PEMBAHASAN Hasil Penelitian}

Bagian ini menjelaskan mengenai analisis hasil penelitian yang ditemukan dilapangan. Hasil penelitian berdasarkan pada data yang diambil dari kegiatan wawancara, observasi, dan dokumentasi. Aspek kajian dalam penelitian ini adalah implementasi pendidikan kedisiplinan siswa di SMA Islam Al-Maarif Singosari Malang.

Analisis data yang dipakai penulis dalam penelitian melalui proses reduksi data yaitu data disaring dan disusun lagi, dipaparkan, diverifikasi dan dibuat kesimpulan. Kemudian hasil penelitian dideskripsikan melalui data uraian sebagai berikut:

Strategi Sekolah Dalam Meningkatkan Pendidikan Karakter Kedisplinan Siswa Di SMA Islam Al-Maarif Singosari.

Sebagaimana dengan Visi sekolah yaitu Mewujudkan insan berkualitas, bertaqwa dan beraqidah Ahlussunnah wal jamaah Annahdliyah, berakhlak mulia, cakap, terampil, mandiri serta berguna bagi masyarakat dan bangsa. Dengan Motto MAJU (Mandiri,
Aswaja, Jujur dan Unggul), maka kedudukan karakter di sekolah tersebut menjadi perhatian yang penting dalam membentuk karakter siswa. Hal tersebut diungkapkan sekolahmemfokuskan pada strategi sekolah dalam membentuk tiga karakter, yaitu pada karakter religius, disiplin, dan peduli lingkungan.

Penelitian ini berfokus pada peningkatan pendidikan karakter kedisplinan siswa. Strategi sekolah dalam membentuk karakter disiplin siswa.Starategi yang dilakukan sekolah untuk meningkatkan pembentukan karakter disiplin pembiasaan kegiatan yang membentuk karakter disiplin adapun pembiasannya meliputi disiplin waktu dan model potongan rambut, cara berpakaian.

Kepala Sekolah SMA IslamAlMaarif Singosari, Titik Susanti, S.Pd menjelaskan bahwa selain disiplin dalam jadwal pelajaran sekolah juga membiasakan siswa disiplin dalam segala hal, misalnya disiplin datang ke SMA, apabila siswa datang telat konsekuensi yang disepakati dengan wali murid adalah siswa berburu sampah di lingkungan sekolah kemudian memasukkannya ke dalam tempat sampah yang sesuai dengan golongannya atau membuang sampah yang telah penuh ke bank sampah dan disiplin memulai jam kegiatan (apel, bersih lingkungan, shalat berjamaah, masuk kelas, membuang sampah pada tempatnya). Model potongan rambut, sekolah memiliki ketentuan model rambut (laki-laki) yang harus dipatuhi oleh seluruh warga sekolah termasuk bapak guru. Ketentuan ini dimaksudkan agar siswa disiplin dan terlihat rapi. Lebih lanjut, Ibu Titik Susanti, S.Pd, menjelaskan sekolah memberikan punishment bagi yang melanggar dan reward bagi yang berprestasi, menjalankan tata tertib sekolah. Implementasi tata tertib sekolah dalam meningkatkan pendidikan karakter kedisiplinan siswa di SMA Islam AlMaarif Singosari

Berdasarkan hasil analisis kegiatan wawancara implementasi pendidikan 
karakter sudah diterapkan terhadap siswa SMA Islam al-Maarif Singosari. SMA Islam Al-Maarif Singosari telah menamkan pendidikan karakter disiplin melalui kegiatan keagamaan dan kegiatan-kegiatan yang berkaitan dengan pendidikan karakter kedisplinan seperti semacam peraturan model potongan rambut, displin waktu, sholat dhuha, dan sholat dhuhur berjamaah. Halinisesuaidenganhasilkegiatanobservasi yang dilakukan yang menggambarkan bahwa pada saat kegiatan rutin yang dilakukan oleh SMA Islam Al-Maarif Singosari memberikan pendidikan karakter tentang nilai-nilai keagamaan, kedisiplinan dan kegiatan sosial. Berdasarkan hasil analisis kegiatan wawancara, observasi dan dokumentasi penerapan pendidikan karakter bahwa pada SMA Islam Al-maarif Singosari sudah menerapkan pendidikan karakter dengan siswanya untuk mengikuti ngaji rutin, membiasakan diri solat dhuha, membiasakan solat subuh berjamaah di awal waktu membiasaka siswa disiplin waktu, cara berpakaaian.

Dampak dari pengimplementasian tata tertib sekolah terhadap kediplinan siswa adalah siswa menjadi terbiasa disiplin waktu untuk datang tepat waktu ke sekolah karena takut diberi hukuman berupa poin dari pihak tatib sekolah, hukuman terberat bagi pelanggar adalah di skorsing dan pemanggilan orang tua apabila melakukan pelanggaran banyak yang membuat poin yang awalnya 100 poin menjadi 25 poin dikarenakan sering melakukan pelanggran.

Menurut Ibu, Chusnul Bariya, S.Pd selaku tatib kesiswaan hukuman paling berat dilakukan sekolah adalah skorsing dan pemanggilan orang tua apabila siswa sudah sering melakukan pelanggaran tata tertib kesiswaan, tujuannya diberikan hukuman tegas adalah memberikan efek jera terhadap siswa untuk selalu disiplin dan mentaati peraturan. Hasil yang diperoleh dengan adanya sanksi bagi pelanggar tata tertib adalah siswa jadi lebih mudah di didik mental dan karakternya serta kedisiplinan para siswa di SMA Islam Al-Maarif Singosari meningkat sehingga selalu mentaati peraturan, dari sebelumnya siswa banyak yang menjadi setiap bulan membuat implementasi pendidikan karakter di sekolah berjalan efektif. sekolah setiap sebulan sekali mengevaluasi tata tertib yang sudah ada, tujuan dievaluasi adalah untuk mengetahui data siswa yang melanggar aturan dan bagaimana untuk cara penanggulan kedepannya. Berikut hasil ringkasan wawancaranya: "Sekolah setiap bulannya melakukan evaluasi kebijakan tata tertib yang tujuannya dievaluasi adalah untuk mengetahui data siswa yang melanggar aturan dan cara penanggulangan kedepannya Hambatan yang di Hadapi dalam Mengimplementasikan Tata Tertib Sekolah dalam Meningkatkan Pendidikan Karakter Kedisiplinan. Berdasarkan hasil wawancara yang pembangkang setelah kena sanksi dilakukan dapat disimpulkan bahwa mereka menjadi penurut dan disiplin dalam penerapan implementasi tata tertib.

Dampak pengimplementasian tata sekolah dalam meningkatan pendidikan tertib terhadap peningkatan karakter kedisiplinan, menurut Ibu Tatik Susanti, S.Pd, Kepala pendidikan karakter kedisiplinan bagi Sekolah SMA Islam Al-Maarif siswa adalah siswa selalu disiplin dalam memanajemen waktu diantaranya sebagai berikut: Siswa selalu datang ke sekolah. Pertama, Lemahnya pengawasan sesuai dengan jadwal yang ditentukan terhadap siswa, sehingga siswa yang dan jarang ada yang telat karena takut melanggar tatib terutama masalah kena sanksi. pakaian kerap kali ada yang lolos dari menurut siswa, guru piket sudah inspeksi. Kedua, Kurangnya sosialisasi datang jam setengah 7 pagi untuk tatib terhadap siswa, sehingga siswa ada mengontrol dan mengawasi siswa yang tidak paham mengenai aturandatang, serta memeriksa kerapihan aturan 
yang ada. pakaian serta rambut siswa. Dengan Hal ini sesuai hasil adanya sanksi, siswa menjadi takut observasi yang menggambarkan bahwa untuk melanggar, sebuah langkah untuk pembinaan itu sendiri terkadang efektif untuk membentuk karakter anak-anak kalau tidak diawasi tertama kedisiplinan siswa di sekolah. lakilaki sering mengeluarkan bajunya.

Berdasarkan hasil wawancara keluar, baru ketika ada guru baju mereka dan observasi penulis, para siswa dirapihkan kembali. Jelas implementasi SMAN Islam Al-Maarif dikarenakan pendidikan karakter tidak begitu diresapi adanya sanksi tegas karena melanggar oleh peserta didik dikarenakan mereka tata tertib, membuat kedisiplinan siswa mau patuh kalau diawasi. Penulis mulai berubah, yang awalnya dulu melihat belum adanya kesadaran dari diri sering terlambat tapi setelah diadakannya evaluasi tata tertib oleh pihak sekolah, siswa sendiri bisa untuk disiplin.

\section{Pembahasan Hasil Penelitian}

Berdasarkan hasil penelitian yang telah diuraikan diatas akan dijelaskan lebih lanjut pada pembahasan dalam subbab ini. Pembahasan akan mengacu pada rumusan masalah. Adapun pembahasanya sebagai berikut :

Strategi Sekolah dalam Meningkatkkan Pendidikan Karakter Kedisiplinan Siswa di SMA Islam Al-Maarif Singosari.

Berdasarkan hasil penelitian yang telah diuraiakan pada hasil penelitian, strategi untuk meningkatkan pendidikan karakter disiplin siswa dilakukan melalui kegiatan pembiasaan kegiatan yang membentuk karakter disiplin. Hidayat (2016) menjelaskan kebiasaan memiliki kekuatan untuk mendominasi tingkah laku seseorang. Dari pengertian tersebut dapat disimpulkan beberapa hal sebagai berikut: pertama, Kebiasaan adalah hasil belajar yang menunjukan pola perilaku tertentu.
Kedua, kebiasaan selalu memunjukan suatu perilaku. Ketiga, Kebiasaan memiliki sifat atau corak seperti: konsisten, otomatis, pasti, mudah, terintegrasi dengan pribadi individu. Berdasarkan hasil pembahasan mengenai strategi sekolah dalam meningkatkan pendidikan karakter siswa dilakukan melalui membiasakan siswa disiplin dalam segala hal. Zaitun dan Siti Habibah dalam Zaenal (2014).

Hasil penelitian Hedianti (2008) juga memperkuat (1) tata tertib di SDN Sukakarya II Samarang Garut ermasuk kualifikasi tinggi, hal ini ditunjukan oleh nilai rata-rata 38,$62 ;(2)$ kedisiplinan belajar siswa di SDN Sukakarya II Samarang Garut termasuk kualifikasi baik, hal ini ditunjukan oleh nilai rata-rata 39,43; (3) pengaruh pelaksanaan tata tertib sekolah terhadap kedisiplinan siswa di SDN Sukakarya II Sanarang Garut ditunjukan oleh a) koefisien korelasi termasuk pada kualifikasi yang sangat kuat. b) hipotesisnya diterima berdasarkan t hitung sbesar 2,061 sedang t table sebesat 2,019 artinya jika baik tata tertib yang ada di sekolah maka akan baik pula kedisiplinan belajar siswa c) pengaruh tata tertib sekolah memiliki pengaruh sebesar 39\% terhadap kedisiplinan belajar siswa dan sisanya $61 \%$ faktor lain yang mempengaruhi kedisiplinan belajar siswa.

Sejalan dengan penelitian yang dilakukan oleh Hediati (2008), Apriani \& Wangid(2015)Penelitiaan ini menunjukkan hasil sebagai berikut. (1) SSP tematikintegratif berpengaruh signifikan terhadap penananaman karakter disiplin. Hasil uji Anova pada skor posttest karakter disiplin antara kelompok kontrol, eksperimen I, dan eksperimen II menunjukkan bahwa nilai $F$ sebesar 18,173 dengan db 86 dan taraf signifikansi 0,00 . Nilai signifikansi lebih kecil dari 0,05. (2) SSP tematikintegratif berpengaruh signifikan terhadap penanaman karakter tanggung jawab antara kelompok kontrol, eksperimen I, dan eksperimen II. Hasil uji Anova pada 
skor posttest karakter tanggung jawab menunjukkan bahwa nilai F sebesar 17,809 dengan db 86 dan taraf signifikansi 0,00. Nilai signifikansi lebih kecil dari 0,05. Data tersebut dapat disimpulkan bahwa SSP tematik-integratif berpengaruh positif dan signifikan terhadap penanaman karakter disiplin dan tanggung jawab siswa kelas III SD Se-gugus 2 Kecamatan Banguntapan.

Berdasarkan data yang sudah didapatkan dan didukung dengan beberapa teori yang sudah diuraikan di atas dapat disimpulkan bahwa strategi untuk meningkatkan pendidikan karakter disiplin siswa di SMA Islam Al-Ma'arifSingosari dilakukan melalui kegiatan pembiasaan kegiatan yang membentuk karakter disiplin dan membiasakan siswa disiplin dalam segala hal.

Implementasi tata tertib sekolah dalam meningkatkan pendidikan karakter. kedisiplinan siswa di SMA Islam AlMaarif Singosari Berdasarkan hasil penelitian mengenai Implementasi tata tertib sekolah dalam meningkatkan pendidikan karakter kedisiplinan siswa. menjelaskan implementasi pendidikan karakter bisa melalui bebeapa faktor, yaitu faktor internal dan eksternal, adapun Faktor eksternal adalah hal-hal yang bersumber dari luar diri pribadi remaja yaitu bimbingan guru, bimbingan orang tua, lingkungan masyarakat dan faktor budaya.

Meningkatkan kedisiplinan bisa melalui kegiatan keagamaan misalnya membiasakan solat berjamaah tepat waktu untuk membiasakan disiplin waktu. Arifin dalam W.I, Riska (2016) menjelaskan sikap disiplin dalam Islam sangat dianjurkan, bahkan diwajibkan. Sebagaimana manusia dalam kehidupan sehari-hari meerlukan aturan-aturan dengan tujuan segala tingkah lakunya berjalan sesuai dengan aturan yang ada.

Kewajiban seorang muslim terhadap waktu adalah menjaganya sebagaimana ia menjaga hartanya. Hendaklah ia bersemangat memanfaatkan seluruh waktunya dalam berbagai aspek yang memberikan faedah dalam agamanya, duniawinya, pengabdiannya terhadap umat dengan baik dan menguntungkan serta peningkatan spiritual maupun material. Selain disiplin terhadap waktu, islam juga memerintahkan untuk selalu konsisten atau disiplin terhadap peraturan Allah yang telah ditetapkan. Hal ini terdapat dalam surat surat Huud ayat 112 yang artinya : "Maka tetaplah kamu pada jalan yang benar, sebagaimana diperintahkan kepadamu dan orang yang Telah Taubat beserta kamu dan janganlah kamu melampaui batas. Sesungguhnya dia Maha melihat apa yang kamu kerjakan". (Q.S. Al-Huud 112).

Menurut Arifin dalam W.I, Riska (2016) Dari ayat di atas menunjukkan bahwa disiplin bukan hanya tepat waktu saja, melainkan juga patuh pada peraturanperaturan yang ada. Menjalankan perintah dan menjauhi larangan-Nya.

Berdasarkan ayat diatas, maka tidak salah apabila memadukan nilai- nilai religius ke dalam peraturan tata tertib sekolah untuk meningkatkan disiplin siswa, karena dalam islam sendiri menekankan prilaku disiplin.

Berdasarkan data yang sudah didapatkan dan beberapa teori yang sudah diuraikan diatas dapat disimpulkan untuk implementasi tata tertib yang meningkatkan pendidikan karakter disiplin SMA Islam Al- Maarif, melalui kegiatan keagamaan dan kegiatan-kegiatan yang berkaitan dengan pendidikan karakter kedisplinan seperti semacam peraturan model potongan rambut, displin waktu, sholat dhuha, dan sholat dhuhur berjamaah.

Hambatan yang di Hadapi dalam Mengimplementasikan Tata Tertib Sekolah dalam Meningkatkan Pendidikan Karakter Kedisiplinan.

Trisnawati (2013) menyatakan kendala dalam membangun kedisiplinan siswa melalui implementasi tata tertib 
sekolah antara lain kurangnya kesadaran diri siswa akan pentingnya disiplin dan tanggung jawab, kurangnya kedisiplinan di rumah, pengaruh lingkungan pergaulan siswa, kurangnya sikap keteladanan beberapa guru dalam ketepatan datang ke sekolah, kurangnya kepedulian dan ketegasan beberapa guru sebagai motivator dalam menegur siswa yang bermasalah dengan tata tertib, dan kurangnya sosialisasi penambahan peraturan baru oleh pihak kesiswaan kepada guru piket.

Berdasarkan hasil penelitian mengenai Implementasi tata tertib sekolah dalam meningkatkan pendidikan karakter kedisiplinan siswa.beberapa faktor yang menghambat diantaranya sebagai berikut: pertama, pengawasan terhadap siswa, sehingga siswa yang melanggar tatib terutama masalah pakaian kerap kali ada yang lolos dari inspeksi. Kedua, Kurangnya sosialisasi tatib terhadap siswa, sehingga siswa ada yang tidak paham mengenai aturan-aturan yang ada.

Suyanto (2014) Hambatan yang dialami sekolah dalam membentuk disiplin siswa melalui implementasi tata tertib bersumber dari faktor internal dan eksternal. Hambatan dari faktor internal yaitu faktor dari guru. Hal ini karena ada guru yang tidak tega memberi sanksi kepada siswa sehingga sanksi yang diberikan tidak sesuai dengan apa yang ada di dalam buku penghubung siswa. Sedangkan faktor eksternal adalah dari siswa. Kurangnya kesadaran siswa untuk mematuhi tata tertib sekolah merupakan faktor penghambat dalam pembentukan disiplin siswa.

Kurangnya pengawasan dan tegasnya guru terhadap siswa bisa menpengaruhi kedisiplinan siswa. Suyanto (2014) Guru selalu memberikan contoh dan teladan sehingga menjadi panutan untuk siswa agar mematuhi tata tertib di sekolah. Akan tetapi ketika ada siswa yang melakukan pelanggaran terhadap tata tertib sekolah justru ada guru yang tidak tega untuk memberikan hukuman kepada siswa. Seorang guru yang menjadi panutan untuk siswa harus menjalankan tata tertib sekolah dengan tegas. Apabila siswa melakukan pelanggaran sudah seharusnya

siswa tersebut mendapatkan sanksi sesuai dengan pelanggaran yang telah dilakukan. Berdasarkan teori tersebut jelas apabila guru tidak melakukan pengawasan dengan benar serta tidak tegas maka akan menjadi penghambat implementasi tata tertib kedisiplinan.

Hamabatan selanjutnya yang harus dihadapi adalah, kedaran siswa, menurut Suyanto (2014) Kesadaran siswa pada umumnya berbeda antara siswa satu dengan yang lain dan pada dasarnya kesadaran lahir dari niat yang sungguh-sungguh dalam hati siswa masing-masing. Siswa dikatakan sadar nilai jika telah memiliki kesadaran dalam dirinya dan perbuatan mana yang baik atau buruk.

Berdasarkan data yang didapatkan dan didukung beberapa teori yang sudah diuraikan diatas dapat disimpulkan bahwaImplementasi kedisplinanan di SMA Islam Al-Maarif Singosari memilki hambatan di bidang eksternal dan internal. faktor internal yaitu faktor dari guru. Hal ini karena ada guru yang tidak tega memberi sanksi kepada siswa sehingga sanksi yang diberikan tidak sesuai dengan yang ada di dalam buku penghubung siswa. Sedangkan faktor eksternal adalah dari siswa. Kurangnya kesadaran siswa untuk mematuhi tata tertib sekolah merupakan faktor penghambat dalam pembentukan disiplin siswa.

\section{SIMPULAN}

Berdasarkan hasil penelitian dan pembahasan pada bab sebelumnya, dapat disimpulkan sebagai berikut: Strategi Sekolah Dalam Meningkatkan Pendidikan Karakter Kedisplinan Siswa Di SMA Islam Al-Maarif Singosari. Starategi yang dilakukan sekolah untuk meningkatkan 
pembentukan karakter disiplin menurut Pak Arif selaku Tatib adalah kegiatan yang membentuk karakter disiplin adapun pembiasannya meliputi disiplin waktu dan model potongan rambut, cara berpakaian. Implementasi tata tertib sekolah dalam meningkatkan pendidikan karakter kedisiplinan siswa di SMA Islam Al- Maarif Singosari.

SMA Islam Al-Maarif Singosari telah menamkan pendidikan karakter disiplin melalui kegiatan-kegiatan yang berkaitan dengan pendidikan karakter kedisplinan seperti semacam peraturan model potongan rambut, displin waktu, sholat dhuha, dan sholat dhuhur berjamaah.

Hambatan yang di Hadapi dalam Mengimplementasikan Tata Tertib Sekolah dalam Meningkatkan Pendidikan Karakter Kedisiplinan. Faktor yang menghambat diantaranya sebagai berikut: pertama, Lemahnya pengawasan terhadap siswa, sehingga siswa yang melanggar tatib terutama masalah pakaian kerap kali ada yang lolos dari inspeksi . Kedua, Kurangnya sosialisasi tatib terhadap siswa, sehingga siswa ada yang tidak paham mengenai aturan-aturan yang ada.

\section{DAFTAR PUSTAKA}

Apriani, An-Nisa \& Wangid, Muhammad Nur. 2015. Pengaruh Tematik-Integratif Terhadap Karakter Disiplin Dan Tanggung Jawab Siswa Kelas III SD. Jurnal Prima Edukasia, 3 (1) 12-25.

Hadianti, Leli Siti. 2008. Pengaruh Pelaksanaan Tata Tertib Sekolah Terhadap Kedisiplinan Belajar Siswa: Penelitian Deskriptif Analisis Di SDN Sukakarya II Kecamatan Semarang Kabupaten Garut. Jurnal Pendidikan UNIGA, 2 (1) 1-8

Hidayat, Nur. 2016. Implementasi Pendidikan Karakter Melalui Pembiasaan Di Pondok Pesantren Pabelan. Jurnal Pendidikan Sekolah Dasar, 2 (2): 128145.
Kementerian Pendidikan Nasional. 2010. Pengembangan Pendidikan Budaya dan Karakter Bangsa: Pedoman Sekolah. Jakarta: Badan Penelitian dan Pengembangan Pusat Kurikulum. Moleong, Lexy. 2001. Metode Penelitian Kualitatif. Bandung: PT Remaja Rosdakarya.

Suyanto, Totok. 2014. Implementasi Tata Tertib Sekolah Dalam Membentuk Disiplin Siswa di SMP Negeri 28 Surabaya. Kajian Moral dan Kewarganegaraan, 2 (2): 243-357.

Sukmadinata, Nana Syaodih. 2009. Metodelogi Penelitian Pendidikan. Bandung: PT Remaja Rosdakarya

Riska. 2016. Metode Pembiasaan Keagamaan Dalam Peningkatan Disiplin Siswa di MTSN Borobudur Magelang Jawa Tengah. Yogyakarta: Fakultas Dakwah Dan Komunikasi, Universitas Islam Negeri Yogyakarta.

Trisnawati, Destya Dwi. 2013. Membangun Disiplin dan Tanggung Jawab Siswa SMA Khadijah Surabaya Melalui Implementasi Tata Tertib Sekolah. Kajian Moraldan Kewarganegaraan, 2 (1) 397-411.

Zaenal, Tatan. 2014. Penerapan Teori Pembiasaan Dalam Pembentukan Karakter Religi Siswa Di Tingkat Sekolah Dasar. Edutech

Zuriah, Nurul. 2007. Metodologi Penelitian Sosial dan Pendidikan. Jakarta: Bumi Aksara. 